\title{
耳鼻咽喉科臨床 第三十二卷 第七號 昭和十二年七月二十日發行
}

\section{論說 \\ 所謂假性}

大阪女子高等醫學專門學校教授

整䑁博士 久 保 正 雄

\section{I 定義}

假性レリループา (Pseudocroup) は Rauchfuss が Gerhardt の小兒科全書に初めて記載した Laryngitis hypoglottica (聲門下腔炎)の異名で あり，從つて鼻漏，咳嗽に始る一種特有な好ん で夜間に起る吸氣性呼吸困難發作症候を云ふの である. Trouseau の所謂Laryngite striduleuse (喘鳴性喉頭炎) b亦之に類する疾患之思はれる. 然し今日迄の多數の文獻を綜合すると假性 レク ループフは必ずしる斯る定型的發作性の8の許 りではなく廣く眞性レクルーブフ (echter Croup) に對する假性レクループ(falscher Croup)といふ 意味にも用ひられてるる. 即ち比較的急劇に來 る犬吹栐咳嗽, 喘鳴, 嘶嗄, 吸氣性呼吸困蜼等 を主徵とする非レデフテリーフ7性炎症性喉頭塽窄 の症候群を綜括する名稱の如く思はれる.私も 亦以下後者の意味に於て本症を論ずるもので今 假に之を所謂假性レクループフと命名して㯰く.

\section{II 原因及誘因}

假性レクループาを一種特有なる非 しヂフテリ 一า性喉頭狹窄症候群之觀る以上其の原因の頗 る多種多㥞に瓦るてとは當然である，定型的發 作性のbのに就ても其の原因に關して種々の見 界がある. 或人は全及喉頭に所見なく單に鼻咽 腔の病變から反射性神經性に起るもの之說明し (Feldstein, Spinola) 又上アレルギーר性發作と考 へてみる人もある(飯田)．然し大抵は聲門下腔 に腫脹隆起等の變化があるもので，稀には泇皮 形成或は粘液附着(Chiari，田中，山崎)等がその 原因之見られた例もある。だが單に腫脹や痂皮 だけで發作の起るものでなく, Blumenfeld は先 驅として發する咳嗽のために秎肉疲勞支來し酸 素の缺乏之炭酸瓦斯の㭸樍が大きな要素をなす もの之云つてみるが更に之に何等かの种經性因 子が伴ふものと思はれる. 非定型的のものに至 つては大抵喉頭聲門下に一定の病變を證明し得 るものであるから先づての部分に於ける異常特 に腫脹隆起を起す原因を尋ねつばならない.そ の前に私が最近 2 ケ年餘の間に吾が呚公に於て 經驗した該患者50例に就て其の原因を觀ると第 1 表の榚になる. 本表で感冒としたのは問診上 俗に風邪之稱するものを總稱したもので此の中 には刎論しインフレンザ性のものも混在してね る. 又他の原因にしても所謂感冒が誘因となつ 
てるる場合が非常に多いのであるが本表では斯 樣なものに對しては感冒の項に容れすれて畺の 原因に基いて記入してるる。

本表中其の主位を占むるものは斻沴と感冒で ある. 文獻に徵しても本症の誘因妁至原因とし ては斯樣な上氣道に變化を及化し易い急性傳染 病が最も多く舉げられ Laryngitis subglottica infectiosa（傳染性聲門下炎)の名稱すらある。

第 1 表 所謂假性レクループフの原因別

\begin{tabular}{|c|c|c|c|c|}
\hline 原 & 因 & 別 & $\hat{\mathcal{E}}$ & 우 \\
\hline 感 & & 冒 & $9(18 \%)$ & $5(10 \%)$ \\
\hline 麻 & & 焀 & $9(18 \%)$ & $7(14 \%)$ \\
\hline 百 & H & 咳 & $1(2 \%)$ & $2(4 \%)$ \\
\hline 脚 & & 氣 & $2(4 \%)$ & $1(2 \%)$ \\
\hline$L \mathcal{Y}$ & 7 & タา & $1(2 \%)$ & 0 \\
\hline 皮 & & 骖 & $1(2 \%)$ & 0 \\
\hline 先 & 天 & 的 & $2(4 \%)$ & $3(6 \%)$ \\
\hline 不 & & 明 & $6(12 \%)$ & $1(2 \%)$ \\
\hline
\end{tabular}

谳疹は其の經過中或は恢復期及それ以後に於 て本症を發する事があり，私の例に於ても第 2 表に示す㭼にての 2 型があり殊に發疹消螁時以 後のものに多い. 麻疹に於ける喉頭の變化に就 ては古來種くの記載あり，Nobécourt（1923)は 之を發疹時又はそれ以前に發生するもの(Frühfälle) とそれ以後に來るもの (Spätfälle) とに別

第 2 表 麻疹の經過と所謂假性クループ 墢生々の關係

\begin{tabular}{|c|c|c|}
\hline 經 過 性 別 & $\hat{o}$ & 우 \\
\hline 發 骖 以 前 & 0 & 0 \\
\hline 發骖 と 同 時 & 1 & 1 \\
\hline 發疹尖 & 0 & 4 \\
\hline 發 骖 消 袙 期 & 4 & 0 \\
\hline 恢復期及それ以後 & 4 & 2 \\
\hline
\end{tabular}

ち，更に之に因る呼吸困難を一過性の假性しク ループフ性のものと永く持續する型とに分けて
みる. 而して通常早期に來るものは肺炎を併發 し易いが呼吸困難は比較的輕く豫後も良いのに 反し晚發性のものには重篤なるのが多くしデフ テリーフの感染を受けた例も尠くないと云つて みる. Gerhardt, 和田, 緒方等は夫々自己の剖 檢例に於て非しヂフテリーフ性義膜を形成せる一 見畺性レクループフと區別出來ない所見を呈する ものあるを報告してるる.然し私の例に於て フタフ性のもの之壞疽性レアンギーナフを合併せ るもの」他一例も斯樣な義膜を認め和只喉頭特 に聲門下の發赤腫脹を呈してみたに過ぎない.

原因之して興味あるは脚氣であつて，脚氣は 元來喉頭筋麻盘を來し易いるのであるが本例に は直達鏡檢查に於てその運動障碍を認めず只腫 脤發赤のみであつた．脚氣は所々に浮腫を形成 するものであり喉頭に於ても稀に之を觀るて之 があり, 吉田はょヴイタミンフB療法に依り治癒し た其の1例を報告し, 加藤も乳兒脚氣を原因とせ る吸氣性喘鳴の例を記載してるる. 斯樣に多少 浮腫爿になり抵抗力の減退せる部位に更に感冒 等により二次感染を受けてレクループ樣症候を 呈することは思考し得可きてとである．私の例 の中1例は1歲の男子-で咽後膿瘍の經過中笑然高 度の呼吸困難, 喘鳴, 犬㕭栐咳嗽等を來し氣管切 開を施したが喉頭に義膜なく只浮腫狀腫脹及發 赤だけで其の後咽後膿瘍が全く減退せるにも拘 らず套管の拔去が困難で而も切開創には其の原 因が見出せず，適々兒科醫から心臟其他に脚氣 栐症候あるを指摘されんベリベロールフ注射を行 ひし所著效を現し 3 日目には套管を拔去するを 得た。他の1例は 3 歲の女兒で之も3日前から漸 次增强する犬吠㥞咳嗽, 嘶㖽, 呼吸困難があり 正達鏡で喉頭特に聲門下の腫脹發赤がある許り 
であつたが念のためょデフテリーフ抗血清の注射 を行つて經過を見たが效果なく，3日目からしヴ イタミンフ療法老行つた所俄然快方に向つた.第 3 例は小兒科に於て脚氣の診炫を附せる 3 ケ月 女兒に於て初めからレヴイタミンフを用ひて治癒 した例である，皮疹としたのは蓴㾁疹様發疹で あるが㟝斷が磼實でないので斯く記载したもの で，2歲11ケ月の男兒に之れに引きつがいて來 た假性レクループרの例である.

先天的に喉頭陝管症候を呈するものは占來多 數の記线があり其の多くは先天性喘鳴 (Stridor congenitus) と稱せられるもので大抵成長と共に 自然治癒に赴くものである. Garfinkel はその原 因として會厭軟骨畸型，甲狀腺及胸腺肥大，下 顎骨異狀及びE大占等を擧げてるる。喉頭自身 の變化としては大抵會厭及披裂皺璧の異常で其 の他に喉頭の元來狹いるのもある. 而して假性 レクループ症候を呈するものは後者に屬するも のであつて, 私の例で男兒の1例は8歲で蒙古人痴 呆の特徵を備へ, 生來再三呼吸困難發作をつがけ 特に犬呋祭咳嗽と吸氣性喘嗚が强い。この患者 のレレフ線像に於て明かに聲門下腔及氣管起始部 の狹窄が認められた．他の1例は25月の幼兒で 巨舌症があるが同時に喉頭狹管を伴つてねた例 である.女兒の3例は凡て35月以下の乳兒であ つて直達鏡下では凡て喉頭入口部の畸型が認め られす聲門下の狹簦が著明であつた．何れも今 闶げけでなく，之迄も同樣のレクループ栐症候 を來したてとがあり先天性と見てよい例と思ふ。

私の症例に觀た原因以外に文獻には猩紅熱 (Hofer, Carril u. Mario, Bonaba, Bario, 高階), レチブスフ (Hirsch), 再跌熱 (Ljubomudrov), 水 痘 (Tiberio: Giuffrida),!_ヘルペスา (Leunda), 先
天性聲門下徽毒 (Louro, 西端, 飯沼)，淋巴組織 腫脹 (T. Watanabe, 前田), 異物 (山川, Pansini, Rossi), 喉頭ヴアンサン氏病 (Zordan, Fernández) 喉頭しオチェーナフ (Chiari，笠原，田中) 等が舉 げられてるる. 此の他て非レヂフテリーフ性義膜 を形成する肺炎双球菌, 連鎖狀球菌, 葡萄狀球菌 几依る非特異性のものがある (Podack, Rebatta \& Parthiodrn, Gittins, Zordan, 和田, 緒方等). 私の例に於ては多數に於て直達鏡下に得た分泌 物から菌檢查を行つて ヂフテリーフ菌を證明し 得なかつた例のみであるが其の他發炎菌の詳し い檢查を行つてみないため大抵連苚兩球菌, 双 球菌が混在し何れが病原菌であるか決定困難な ため茲には記载しなかつた。

本症の年蛉は殆んど小兒に於て見らる」もの であつて臨床的興味も亦眞性レクループフの好發 年龄である小兒期にある．參考までに私に於け

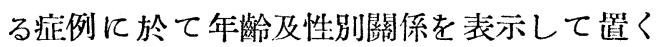
(第3表)，只興味あるは本症は真性 レクループר が比較的少い乳兒に相當多數見5けられるこよ で, 又幼㪘程多いといふととは喉頭の廣さ, 粘膜

第了表 所謂假性レクループフの年龄及性別關係

\begin{tabular}{|c|c|c|}
\hline 年 䍅 & $\hat{o}$ & 우 \\
\hline 1 歲以下 & $6(12 \%)$ & $3(6 \%)$ \\
\hline 1歲—2歲 & $4(8 \%)$ & $3(6 \%)$ \\
\hline $2-3$ & $8(16 \%)$ & $1(2 \%)$ \\
\hline $3-4$ & $4(8 \%)$ & $3(6 \%)$ \\
\hline-5 & $3(6 \%)$ & $5(10 \%)$ \\
\hline $5-6$ & $3(6 \%)$ & $1(2 \%)$ \\
\hline $6-7$ & $1(2 \%)$ & $2(4 \%)$ \\
\hline $7-8$ & $1(2 \%)$ & $1(2 \%)$ \\
\hline 12 歲 & $1(2 \%)$ & $0(0 \%)$ \\
\hline 計 & $31(62 \%)$ & $19(38 \%)$ \\
\hline
\end{tabular}

の抵抗性といふ點から考へて興味がある. 仯男 子は女兒よりも 1.5 倍以上にも及んでるるがそ 
の原因は不明である.Thomson の統計ではその 比が $76: 35$ で私のものと一致するが Csillag の 統計は男子よりる女子が多くなつてねる.

\section{III 症候}

既述せる樣に本症を非しヂフテリーר性聲門下 狹窄症候群と解する以上, 其の主要症候は該部 の喉頭しヂフテリーフに於ける症候郎ち犬吠樣咳 嗽, 嘶嗄, 吸氣性喘鳴及び呼吸困難等であつて 只兩者の間に各症候發現の掘速, 輕少, 經過等 几多少の逕庭を有するのみである。勿論所謂假 性レクループרを起す原因疾患に特有な症候を具 備してねる.

所謂假性レクループาの症狀發現は一般に漸進 的であつて, 定型的な發作を來するのでも發作 以前から鱟漏を訴人犬吠樣咳嗽の先行するるの である. 又呼吸困難, 喘鳴等の急迫症候もしヂ フテリーフの樣に常に增强して行かず, 概ね日に より時に隨つて多少の消長を示するのである.

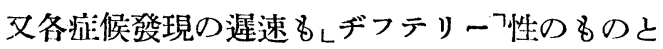
異つて假性しクループרに於ては犬吠樣咳嗽が最 も初期に現はれることが多く嘶㖽や喘鳴は大抵 之に遮れて發しょヂフテリーフ性のものに比して 嘶嗄の程度は輕い（第 4 表）。大吠樣咳嗽の樣な

第 4 表 所謂假性レクループר初發症候

\begin{tabular}{|rrrr|rr|}
\hline 犬 & 㕭 & 樣 & 咳 & 嗽 & $31(62 \%)$ \\
喘 & & & 鳴 & $9(18 \%)$ \\
嘶 & & & 嗄 & $5(10 \%)$ \\
呼 & 吸 & 困 & 難 & $5(10 \%)$ \\
\hline
\end{tabular}

初發症候が現はれてから逼迫せる呼吸困難を呈 する迄には相虽の時日を要するから醫師の門を 川くまでにも相當の時日を置いても危險の少い てとを第 5 表が示してみる. 勿論その日の中に 來るものが多いが此の數字の一つは咳嗽のため
に兒科醫を訪れ，それから直ぐ吾々の方に迴し て哭れたなめでもある．鬼に角4一5日といふ例 が可成り多いのはレヂフテリー性のものに比し て病勢が比較的緩慢で消長を示すためと解して よから5.序に原因疾患の發生から初發症候發 現迄の日數を揭げて置く，即ち本表は所謂假性 レクループフには晚發性のものが多いてとを示し てみる.

第 5 表 所謂假性レクループ7初發症候發現狀況

\begin{tabular}{|c|c|c|c|}
\hline & & $\begin{array}{l}\text { 原因疾患發生 } \\
\text { より初發症候 } \\
\text { 發現まで }\end{array}$ & $\begin{array}{l}\text { 初發症候發 } \\
\text { 現後初診迄 }\end{array}$ \\
\hline 1 日 以 & 內 & $2(4 \%)$ & $15(30 \%)$ \\
\hline 2 日 以 & 內 & $2(4 \%)$ & $7(14 \%)$ \\
\hline 3 H 以 & 內 & $4(8 \%)$ & $5(10 \%)$ \\
\hline 4 日 以 & 内 & $2(4 \%)$ & $6(12 \%)$ \\
\hline 5 日 以 & 內 & $0(0)$ & $6(12 \%)$ \\
\hline 10 日 以 & 內 & $13(26 \%)$ & $4(8 \%)$ \\
\hline 15 日 以 & 內 & $2(4 \%)$ & $1(2 \%)$ \\
\hline 1 ケ 月 以 & 內 & $10(20 \%)$ & $3(6 \%)$ \\
\hline 1 ケ月以 & 上: & $5(10 \%)$ & $1(2 \%)$ \\
\hline 生 & 來 & $4(8 \%)$ & $2(4 \%)$ \\
\hline & 明 & $6(12 \%)$ & $0(0)$ \\
\hline
\end{tabular}

\section{IV 診 斷}

犬以栐咳嗽, 吸氣性喘鳴乃至呼吸困難があれば 先づ聲門下腔に狹窄があるものと看做してよい. 診斷的興味は一に斯る狹窄がレヂフテリーフ性の ๖のか否かに存する. 郎所謂假性レクループフは その原因疾患に關係せる冬個の鑑别的議論を措 けげ凡ゆる急性炎症性聲門狹窄症から Lヂフテ リーフを除外すれば足りるのである，ての意味 に於て最も確實な診斷法は局所に於けるレデフ テリーフ菌の證明である. 然し單に塗抹標本で のみ之を知るこ之は甚だ危險で，それる必和㬋 頭內分泌物から檢せねばならない，最も破實な る方法は菌培養であるが Thomson は 697 例の 喉頭んヂフテリーフ性呼吸困難例で咽頭から得た 
材料では50\%，喉頭から得たもので85\%の陽性 率を擧げてみるに過ぎず, 何度も何度も絽返し た檢查の後に初めでヂフテリーフ菌は證明し或 は最初全く假性レクループ發作症候を繰返し遂 には眞性レクループาとなつた例を報告されてる る (Leunda) から菌檢出は慎重に何间它之を行 はねばならない、シツク反應も參考になる，然 し之等の檢查には相當時間を要し其の結果を待 つととの出來ない場合が多いのであるから先づ 鼻腔咽頭等にடヂフテリー、性病變の存否を確め (Thomson はレヂフテリー性レクループาの全例 の38\%に於て咽頭しヂフテリーフの合併を見てる る), 更に喉頭鏡檢查に依つて義膜の有無を檢せ ねばならない，旣述した樣に假性しクループで も義膜のあるものがあり又小川は義膜を作らな い所謂加答兒性レヂフテリーフを擧げてるるから 此等の點も考虑に入れる必要がある. 喉頭鏡檢 查は少し大きな小兒なれば間接法で十分である が幼兒は殆んど之は不可能で凡て直澾鏡に據ら ねばならぬ. 私の50例の約 3 分の 2 は吉田式值達 鏡を以て檢したものである. 然し直達鏡でも氣 管の深部にだけ義膜があつた例も報告されてね るから注意が要る. 直達鏡檢查に於て患者が騷 ぎ號泣するためと器具による壓迫のために㸴に 相當の發赤を來すものであるが，それにも增し て所謂假性レクループרの喉頭には發赤腫脹が見 られ輕微なるのは會厭喉頭面, 披裂部, 假聲帶及 聲門下腔に存するが後には聲帶にも及び他の部 分も顯著になる. 義膜乃至泇皮を形成する場合 でも聲帶に沉發性に存することは尠く聲門下又 は假聲帶, 會厭, 披裂部等に散在性に認められ る. 私の例では1例 (6歲す)に之を見たが再三の 菌檢查でレヂフテリーフ菌が證明され市葡萄狀球
菌及連鎖狀球菌が發育し，乙の患者は逐に壤疽 性扁桃腺炎を合併して敗血症々候に依つて死亡 した. 他に アフタา性の 1 例がある. 兩側とも 苔は局在性であつた．所謂假性レクループ喉頭 にはよく粘稠なる分泌物の附着してるるてとが ある.之と義膜とを誤つてはならない。

之等喉頭所見から 想像出來る樣に所謂假性 レクループフの初期症候は前にも述へたが聲門下 の腫脹に由來する犬吠樣咳嗽を以て始る，且症 候の發生は逐次的漸進的で後になつて多少の嘶 嗄を來すがしヂフテリーフの樣に無撀にまで陷る ことは尠く, 喘鳴, 吸氣性呼吸困難をで到るに は若干の時日があり又時により多少の消長增減 を星するものである，反之レヂフテリー性のも のは犬吠樣咳嗽，嘶嗄は殆んど同時かむしろ嘶 嗄から先に來ることが多く一旦喘鳴，呼吸困難 が發現すると刻々症狀が惡化して重篤なる狀態 几陷る. 從つて一般狀態もレヂフテリー性のも のは激甚で强度のレチアノーゼ?を伴ひ患兒は全 く氣力消沈，只酸素を得るために全勢力を注ぐ といふ感じがする．假性レクループาでは呼吸困 難の割合にடチアノーゼフの度が輕く元氣があり 時には割合本然としてるる樣に見える.此の點 は Posthuma を始め多くの學者が認めてねる. 假性レクループרの聲音變化は輕く號泣等の場合 几は永く澄んだ明膫な音が出る，同樣に犬吠樣 の陔嗽もや」高く澄んでるる，反之しヂフテリ 一า性の嘶嗄の强いのに比例して咳嗽も響が 弱く何かしら空虛な感じがする. Zschocke u. Siegmond \&此の點を兩者の鑑別に用ひてるる. 然し多少の例外といふ事は常に考虑に置く可き で Thomson もレヂフテリーフでも無聲とならな いものがあり $(20 \%)$, 非「゙゙フテリー性のるの 
でも無聲の例があると云つてるる。

喉頭聽診法も診斷の一助になる.郎ち假性レク ループาはや」レラフ音樣であるが眞性レクルー プフでは低調の剈音を聽くといふ、Levinsohn 氏 症候も或程度の信用は置ける. Zschocke u. Siegmond の云ふ㥞にடヂフテリーר義膜の翩翻 音を聞き得る事もある. 少成書或は文獻に假性 レクループ特に急性氣道炎症に合併或は續發す るものには高熱を伴ふ樣に記戎し之を真性 レク ループフとの鑑別に舉げてるるが私は之には贊 成し策ねる，血液所見も原發症に左右される場 合が多いので餘り意義がない，Thomson は喉 頭レヂフテリーフ 697例中咽頭に所見のあつたも のが245例 $(38 \%)$ と云つてみるから咽頭の所見 は診斷上參考になるが, 面白いことには咽頭の發 赤が同時に存してそ水が可成高度なるに拘らず 義膜の存しない場合は多くは假性しクループ7で， レヂフテリーフ性のものには斯樣な場合大抵義膜 を扁桃腺又は其の周圍に證明出來る. 頸部淋巴 腺腫脹も參考になるが重視してはならない，藤 森，橫田等は $1 \%$ டアドレナリンフを $0.1-0.2 \mathrm{cc}$
皮下に用ひ假性レクループフでは症候の輕減する 點を鑑別に使つてるるが之も簡單で相當の價值 があり，同㭙に强心性に働き血清をなす場合しシ ヨツクาの像防にもなる。私は同時に局所の塗 布も行つてみるが成績が一層顯著である・レヂフ テリーフ 抗血清の效果を以て鑑別に用ふること は最も安全であり確實であららが濫用される嫌 がある．劣木村氏は兩者の鑑別に尿中ょアセト ンフ出現の有無を述べて居り, 郎ちょヂフテリーフ では常に陰性であり扁桃腺炎では大抵陽性であ るから尿中レアセトン陽性で他のレヂフテリーフ 所見のないものは先づレ゙゙フテリーフを除外出來 ると云ふのである，私は此の說を批刵するため 最近我が病院の當耳鼻咽喉科及び兒科入院患者 中急性氣道疾患で尿檢査の詳細に行はれたもの 119例に就て調べて見た．其の成縝は第6表の通 りでレヂフテリーフ性必ボしも陰性ならず殊に假 州レクループาとの差はなく，參考までに附記し たレウロビリノーダン發現率と略々正比例し鑑 別上意義ないてとが解つた。

第 6 表 急性氣道疾患尿川ょアセトンフ出現率

\begin{tabular}{|c|c|c|c|c|c|c|}
\hline \multirow[b]{2}{*}{ 病 名 別 } & 蛋 & 白 & $ア \quad 七$ & ע & \multicolumn{2}{|c|}{ ウロビリノーゲン } \\
\hline & $(+)$ & $(-)$ & $(+)$ & $(-)$ & $(+)$ & $(-)$ \\
\hline ヂ |鼻ヂフテリー & $1(14.3)$ & $6(85.7)$ & $2(28.6)$ & $5(71.4)$ & $1(14.3)$ & $6(85.7)$ \\
\hline 咽頭ヂフテリー & $9(42.9)$ & $12(57.1)$ & $5(23.8)$ & $16(76.2)$ & $6(28.6)$ & $15(71.4)$ \\
\hline 喉頭ヂフテリー & $5(83.3)$ & $1(16.7)$ & $3(50.0)$ & $3(50.0)$ & $4(66.7)$ & $2(33.3)$ \\
\hline 咽喉ヂフテリー & $4(66.7)$ & $2(33.3)$ & $2(33.3)$ & $4(66.7)$ & $2(33.3)$ & $4(66.7)$ \\
\hline インフレンザ & $6(35.3)$ & $11(64.7)$ & $7(41.2)$ & $10(58.8)$ & $5(29.4)$ & $12(70.6)$ \\
\hline 肺 & $16(50.0)$ & $16(50.0)$ & $2(6.2)$ & $30(93.8)$ & $5(15.6)$ & $27(84.4)$ \\
\hline 将 & $9(75.0)$ & $3(25.0)$ & $7(58.3)$ & $5(41.7)$ & $3(25.0)$ & $9(75.0)$ \\
\hline 咳 & $3(42.9)$ & $4(57.1)$ & $2(28.6)$ & $5(71.4)$ & $1(14.3)$ & $6(85.7)$ \\
\hline 假 性 ク ループ & $4(36.4)$ & $7(63.6)$ & $2(18.2)$ & $9(81.8)$ & $2(18.2)$ & $9(81.8)$ \\
\hline
\end{tabular}

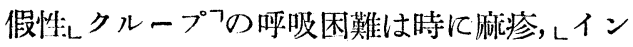
フレンザフ百日咳等に合併し易い肺炎と鑑別を要
するてとがある，後者の場合には吸氣性ではな く夆として呼吸面積減少によるものであるから 
鼻翼呼吸，呼吸數增加が著しきに反し鎖骨窝， 胁間, 腹壁の陷入が著明でない. 又肺所見が特 有である. 此の他假性しクループ は之れを誘發 する原因の探求鑑別は重要な部門であるが茲で は省略して置く.

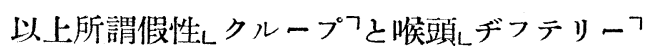
との鑑別點を綜括して第 7 表に表示して稙く.

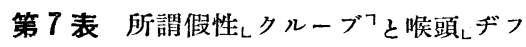

テリーフとの鑑別姴網

\begin{tabular}{|c|c|c|}
\hline 鑑別點 病名 & $\begin{array}{l}\text { 所謂 假 性 } \\
\text { ク ル } フ^{\circ}\end{array}$ & $\begin{array}{l}\text { 喉フテ頭 } \\
\text { ヂフテリ }\end{array}$ \\
\hline 發 生 & 漱進的 & 突發的 \\
\hline 初留症 候 & 犬呋樣咳嗽多し & 斯嗄多し \\
\hline 一般狀態惡化 & 輕微 & 激甚 \\
\hline チアノーゼ & 輕微又は無し & 强度 \\
\hline 罄 音 變 化 & 遲く且輕度 & 早期に來り强度 \\
\hline 咳 & 高調の犬呋樣 & $\begin{array}{l}\text { 低調にして空虛 } \\
\text { なる犬呋樣 }\end{array}$ \\
\hline 呼 吸 困 難 & $\begin{array}{l}\text { 綾徐に來り 輕度 } \\
\text { で消長むり }\end{array}$ & $\begin{array}{l}\text { 俄然來り强度で } \\
\text { 刻々惡化す }\end{array}$ \\
\hline 義 & 無きか局部的 & 汎發性にあり \\
\hline 咽喉發赤腫脤 & $\begin{array}{l}\text { 咽頭に强くとを } \\
\text { 義膜なし }\end{array}$ & $\begin{array}{l}\text { 咽頭に强ければ } \\
\text { 義膜あ }\end{array}$ \\
\hline 罄帶の變化 & 退發して輕度 & $\begin{array}{l}\text { 早期に發して强 } \\
\text { 度 }\end{array}$ \\
\hline ヂフテリー菌 & 陰性 & 陽性 \\
\hline $\begin{array}{l}\text { Levinsohn 氏 } \\
\text { 差住 }\end{array}$ & 稍々レラフ音樣 & 低き削音性 \\
\hline 淋巴腺腫脹 & 輕度 & 著明 \\
\hline $\begin{array}{l}\text { アドレナリン } \\
\text { 泩 射 }\end{array}$ & 症候輕快す & 影響少し \\
\hline Schick 氏反應 & 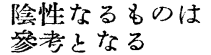 & 陽性 \\
\hline $\begin{array}{l}\text { F゙フテッー抗 } \\
\text { 血淸 }\end{array}$ & 影響少し & 效果著明 \\
\hline
\end{tabular}

\section{$\mathbf{V}$ 嬁後}

反射性に來る定型的發作性假性レクループ7は 其の原因を追求して治療すれば䂆後は一般に良 い. 反之麻疹，レインフレンザ?，猩紅熱等に合 併又は續發する所謂假性レクループフの峥後は必 ずしも良好とは云へない，幸に吾々の例では抗 血清を用ひないものに 1 例，血清を用ひたるも の2例，(中1例は氣管切開を施行) 都合 3 例の死
亡者を出したのみであるが(第8表)，文獻に現は れた數字は更に高率を示してみる.今其の若干 走す之 Thomson は113例中に於て挿管を行 ひしもの14例中 9 例, 之を行はざりしもの99例 中5例の死亡例を報告し, Gittins は14例の中10 例氣管切開を行ひ 6 例死亡して居り, Blato u. Hilleboe は97例の非レヂフテリー性急性喉頭狹 窄に於て $40 \%$ 死亡例を報告してるる. 之を病 名别に見ると床疹後のものでは緒方は5例中2例， 安藤は3例中1例，私の例で啝疹を原因とする 16 例中2例まで死亡してるる. Nebécourt は秒疹で は晚發性のものが危險であると云つてるる・レチ ブスา性のものは Hirsch が90例中 $17 \%$ ， レン フレンザา性のものではは Bargo は8例中2例の 死亡例を報告してみる. 之等の死因は大抵氣管 枝肺炎で本症に氣管切開の危險を主張する人る ある所以である．私の死亡例の死因は氣管切開 創の壞疽性變化飞依る血管破裂, 壞疽性扇桃腺 炎合併による敗血症及び心臟㳖弱である。治癒す る場合に於ても抗血清に於けるレヂフテリーフの 樣に速かでなく呼吸困難だけでも數日から10日 餘りる姴することがあり, 犬吠榚咳嗽は更に掘 れて2一3週を要するてとは稀でない. レチブスา が趣歸熱性の潰瘍を作るものでは般痕が殘り, 中島は麻疹で馨帶癒着を來した例を報告して居 る. 然し通常何等跡を殘すてとなく治癒するも のである. 又先天性のものは成長するに從ひ自 然治癒するてとが多い。

第 8 表 所誚假性レタループフの豫後

\begin{tabular}{|rr|r|r|r|}
\hline & $\begin{array}{r}\text { ヂフテリー抗血 } \\
\text { 清泩 }\end{array}$ & 行はず & \multicolumn{2}{|c|}{ 行ひしもの } \\
\cline { 3 - 5 } & 氣管切開 & $($ 後 & $(-)$ & $(+)$ \\
\hline 治 & 療 & $37(74 \%)$ & $7(14 \%)$ & $1(2 \%)$ \\
死 & 亡 & $1(2 \%)$ & $1(2 \%)$ & $1(2 \%)$ \\
不 & 明 & $2(4 \%)$ & 0 & 0 \\
\hline
\end{tabular}




\section{VI 治 療}

豫防として好んで氣道を侵す磨琌，百日咳， レインフレンザフ，猩紅熱等の急性傳染病の際氣 道の衙生に十分注意する之共に體質にも一定の 關係があるから此の方面に對する日頃の鍛鍊を 必要とする．少先天性に僅かな風邪等ですぐ喘 鳴を來し易い小兒には十分此の方向にも保護を 急つてはならない。

治療上最る問題になるのはレヂフテリーフ抗血 清である. Martin や Coldrin は麻疹後の呼吸困 難の95-100\% にடヂフテリーר感染を見，河野 は60-70\%の發現率を示し，Thomson は810例 の呼吸困難中697例の レヂフテリーフを證明し， Plato 等も 352例中255例の レヂフテリーาを觀察 し，之等の結果から殆んど全ての學者は初期大 量血清の使用をす〉めてるる. 其の使用量も大 量で Martin は25,一30,000單位を一時に投與し， 本邦で多大量使用論者が多く大抵 10,000 單位內 外を使つてるる，然し斯栐に大量の血清を一時 に用ふるてとは却つて心臟の負擔を大きくし， 他方內皮網狀組織の機能を減退せしめ解毒喰菌 作用を低下せしむる危險がある．現在迄の本邦 死亡例を見ても血清の用ひられてなないものは 少い. 此の意味から私は血清の使用は分割的に 施行するてとっ，血液其の他を以て代用するこ とを提唱し度い. 又直達鏡に依る所見及び菌檢 查並に前述の各項鑑別要綱を吟味するならば血。 清の篮用も或程度迄避け得ると信ず. 吾が呚室 の例では血清を用ひたものは僅かに10例 (20\%) で血清を用ひずに死亡したのは僅かに 1 例に過 ぎない. 又 ヂフテリーフを誤つて血清注射の時 期を逸したといふとともない。

呼吸困難に對する外科的處置並に插管法の可 否多議論されてるる. 議論の要點は假性 レクル ープーでは義膜形成よりもむしろ腫脹が强いの
であるから插管法に依る刺戟は病症を惡化さす と云ひ管切開は只さへ起し易くなつてみる 肺炎を誘發する惧が十分にあると云ふので何れ にしても經過を惡くする．然し處置の罷むを得 ない場合を多々あるから其の場合何れかを探ら ねばならない. Berggrenの云ふ樣に㨂管法の害 はむしろ大きく，後で大抵氣管切開を行はなけ ればならなくなるから初めから氣管切開を行ふ 方が安全である。

斯る急救處置を成る可く避け度いといふ意味 に於でアドレナリンフ(飯田, 藤森)，ᄂエフェド レリンフ(Coccheri), ᄂエフェトニンフ (Colarizi)を 皮下乃至局所に用ひて效果を得てるる。本法は 吾が呚室でも全例に用ひ治憭のみなら北診斷的 にも役立つてとを知つた. 少し變つた所では高 須は谳疹恢復期呼吸困難の 2 例飞 $3 \%$ 硫酸銅液 30-50cc 飲ませて嘔吐, 咯出老促して成功して みる．昔食道異物の吐劑として用ひたるのであ るが少し興味がある. Gittins 等も義膜や咯掞を 器械的に吸引清掃するへきてとを主張してるる。 吸引裝置のある直達鏡はての目的には合理的で ある。

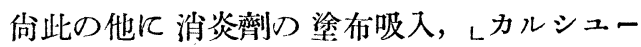

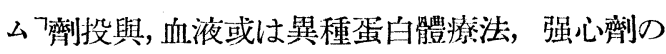
注射等が行はれてるる・我が㸚室では局所に $2 \%$ レプロタルゴール7液, レアドレナリンフ塗布, 注 射娈としてょカルチコールフ,ムエレクトラルゴー

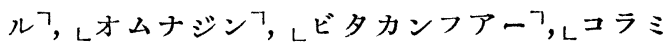
ンフ，血液注射等の他に常にடヴイタミンフB劑の 投與を忘れず，最近は更によヴイタミンフCを投 與してみるが成績が良い。

又之等諸療法と共に原因疾患を探求して之が 治療徹底的に行ふべはは言を俟たない。

(文獻省略) 